\title{
Ensuring Human Safety in the Disaster Prone Coastal Town of Limbe, Cameroon
}

\author{
Sunday Shende Kometa ${ }^{1}$ \\ ${ }^{1}$ Department of Geography, Faculty of Social and Management Sciences, University of Buea, Cameroon \\ Correspondence: Sunday Shende Kometa, Department of Geography, Faculty of Social and Management \\ Sciences, University of Buea, Cameroon. E-mail: shendeK@hotmail.com
}

$\begin{array}{lc}\text { Received: February 28, } 2012 & \text { Accepted: March 23, } 2012 \quad \text { Online Published: May 28, } 2012 \\ \text { doi:10.5539/jgg.v4n2p156 } & \text { URL: http://dx.doi.org/10.5539/jgg.v4n2p156 }\end{array}$

\begin{abstract}
Limbe in Fako Division of the South West region of Cameroon is located in an active and dynamic coastal zone characterized by geological, geophysical, geomorphologic and climatic hazards. This paper examines the nature and occurrence of hazards in this region with the objectives to recommend measures for ensuring human safety within this dynamic environment. The frequency of volcanic eruptions, seismic activities, landslides, flooding and coastal erosion has had adverse consequences on human lives, property and the environment in the city. In this regard, human occupation of high-risk zones (hill slopes, floodplains, and coastal lowlands) is the source of problems of habitation in this region. Based on the concept of urbanisation, vulnerability and exposure to risk, and using the DR - Disaster Risk Index, drainage, relief, topographic maps, risk zones were identified. This paper recommends the evacuation of people from some of these risk zones and in other relocating. These hazard prone areas do not only require careful policy planning but also require a rigorous implementation of the strategic master plan of the city.
\end{abstract}

Keywords: urban development, physical exposure, vulnerability, risk, risk management

\section{Introduction}

The beginning of the second half of the Twentieth Century was a turning point in the process of urbanisation in most Third World countries in general and Sub-Saharan African countries in particular. The urban population in this region of the world increased from less than $20 \%$ at the beginning of this period to about $50 \%$ today (United Nation Development program, 2006). This unprecedented rate of urbanisation has been associated with the increasing concentration of population in cities and significant transformations of the urban landscapes with the emergence of structures as well as activities that put the population at risk particularly where geological, geomorphological and climatic components come into play (Goudie, 1990).

Uncontrolled city expansion with the occupation of disaster-prone zones has predisposed the urban population, especially those in squatter settlements to the negative effects of climate change triggering hazards such as floods, landslides and coastal erosion. In the past two decades, the rate of urbanisation has been unprecedented in some Cameroonian cities. The attendant consequences have been the development of slums. The causes of this rapid urbanisation are related to the decline in the profitability of rural livelihood activities like the sustained fall in commodity prices, scarcity of farmland, and the attraction of city life all of which conspired to push out millions of rural dwellers to start a new life in towns and cities.

Increasingly, evidence from around the world suggests that the global climate is already changing as a result of human actions. Precipitation has increased by about $1 \%$ throughout the world in the last century. High latitude areas are tending to witness more rainfall, while precipitation has actually declined in some tropical areas (Nieuwolt, 1978). Warmer temperatures are causing more evaporation and this is expected to produce more severe storms, hurricanes, typhoons, tornadoes, rainstorms, and damaging floods especially for cities located along the coast (Dinar et al., 2004). In the face of these hazards, large urban populations are forced to settle in marginal areas dominated by recent and poor rural-urban migrants. These marginal areas include swamps, valley floors, and the urban fringe areas where the value of land is low and competition for it is still less keen. Hill slopes, earthquake and volcanic-prone areas are also solicited. These new environmental conditions have extended the ranges of vulnerability of people exposed to risks. 
A review of the concepts of urbanisation, urban planning, environmental constraints to development and vulnerability was useful in situating this work within its proper conceptual framework. This paper therefore surveys the state of urban settlement, vulnerability to hazards and human safety in Limbe. Drawing primarily from recent literature on the area, geological and climatic data and data on floods, landslides, coastal erosion and earthquakes, it outlines the influence of geology, relief, and drainage on settlement and human safety. Some recommendations are discussed which could be applied to reduce the occurrence of these hazards in the area under investigation.

\section{Methods and Materials}

Topographic, climatic and geological maps were used to give a rough idea of the scale of the problem in the area. Semi-guided interviews and questionnaires were administered to some members of the Limbe City Council and some inhabitants of the affected areas. Measurements of the scars left by landslides were taken and angles of slope were measured to evaluate their impact on erosion and the incidence of landslides. Tension cracks produced by tectonic activity (earth tremors) were examined and their network, intensity and length investigated to evaluate their contribution to landslides in this region. Rainfall data from the Cameroon Development Corporation's (CDC) meteorological station were used to enable an assessment of rainfall intensity, duration and variation over the years. The water table as well as the size and depth of storm drains were measured to assess the efficiency of these structures in floods prevention and control.

Rainfall data from 1991-2005 provided the timing and the return period of heavy rainfall and floods in the area. Figures for the number of human lives lost and the estimated property damage for each landslide and flood episode for Limbe, from 1980-2005 were provided by the Limbe Urban council. The Limbe Botanic Garden also provided vital data which was equally supplemented by field data. Data on the seismic activity in the region were collected from the earthquake monitoring station at Ekona. This station as well as the Mount Cameroon Project Office in Buea provided data on past eruptions of Mount Cameroon which enabled the calculation of the average length of time for periods of quiescence. This enabled us to make predictions as to when the latter was likely to erupt again although volcanic activity is extremely unpredictable. The Disaster Risk Index (DRI) developed by the UNDP was used to measure and compare the relative level of physical exposure, vulnerability and risk. This enabled us to identify the vulnerability indicators that point to development processes contributing to the configuration of risk. The use of the DRI here was guided by the use of a conceptual framework that seeks to explain urbanisation, vulnerability and risk.

Vulnerability according to the UNISDR (2001) refers to the conditions determined by physical, social, economic and environmental factors or processes, which increase the susceptibility of a community to the impact of hazards. Vulnerability links social-economic structures, cultural norms and values and environmental hazards and disasters in a causative chain. The potential of a disaster to occur depends on a population's vulnerability or coping capacity in the face of such a shock. This capacity seems to be reducing as global warming intensifies. Understanding the vulnerabilities of places and groups of people is an essential first step in mitigating the risks of disasters. This is done through understanding and underscoring the processes of urbanization, impoverishment and building resilience in a population. In the case of low resilience and high vulnerability in the population, disasters may well be considered the results of failed developmental policies and practices which tend to increase vulnerability and reduce coping strategies, constraining development further in a downward spiral The vulnerability of the urban poor to hazards can be reduced through capacity-building and livelihood resilience to disaster risks. Disaster can thus be defined as the combination of hazard and vulnerability.

\section{Physical and Antropogenic Landscape}

Limbe is located between latitudes $4^{\circ}$ and $9^{\circ}$ North of the equator and between longitudes $9^{\circ} 10^{\prime}$ and $9^{\circ} 31^{\prime}$ East of the Greenwich Meridian. It occurs along the rocky coast of Cameroon and covers a surface area of about 674 $\mathrm{km}^{2}$ (Limbe Town Planning Office, 2000). It is the link between the ocean and the continental segment of the Cameroon Volcanic Line (CVL) and is found where the Cameroon Mountain extends into the Gulf of Guinea. The town is characterised by irregular relief made up of highlands and lowlands. The surface area therefore, is confined between the surrounding hills and the Atlantic Ocean (Figure 1). These hills are volcanic cones made up of scoriaceous material that have been deeply weathered thus rendering them unstable and vulnerable to slope movement. The topographic layout of Limbe shows a basin-like structure with a number of topographic elevations. This coastal lowland is drained by the River Limbe and other streams such as the Jengelle, Ngelle and the Manga which takes its rise from New Town and meanders its way until it reaches the ocean. Given the diversity of physical features and the limited available land, planning schemes are difficult to initiate and 
implement. It is thus, a difficult zone for settlement and many forms of human activity as it is constantly affected by seismicity, vulcanism, floods, landslides and coastal erosion.

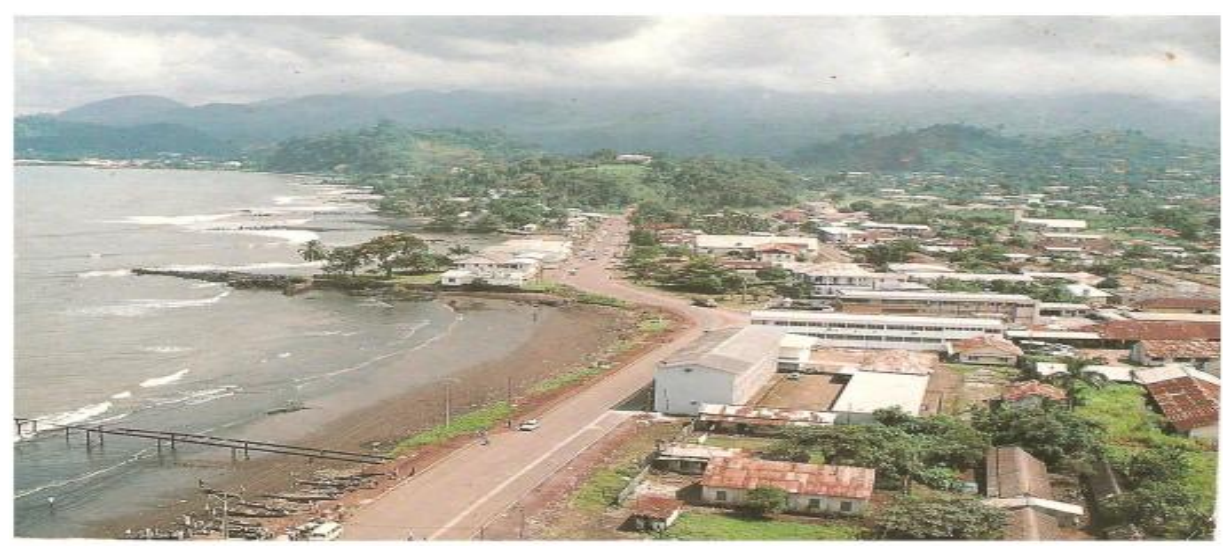

Figure 1. Partial View of view Limbe showing arms of the sea extending into Land

The figure is a partial view of the Limbe Municpality in terms of the extent of sea inland relative to the built-up area

The rugged topography (with scoriaceous hills and steep slopes) limits space for human settlement and urban expansion. Most of the area which is suitable for settlement is a few metres above sea level. It is seismic and an active volcanic zone. With its frequent seismic and volcanic activity with quiescent periods that range from one to fourty-one years, this area is active. The climate of this area is tropical monsoonal and characterised by two main seasons, the wet season with heavy rains and the dry season. Maximum rainfall is recorded between June and July while minimum rainfall is obtained between December and January. The mean annual rainfall lies between $2000 \mathrm{~mm}$ and $4000 \mathrm{~mm}$. The variation, however, between the wet and dry season rainfall is great. The high amounts of rainfall at this coastal location are clearly the result of orographic effect. Mount Cameroon rises up from the shores of Limbe and, because it comes close to the coast, this causes heavy orographic rainfall. Moreover, the area lies in the path of the SW Monsoons which blow over the Atlantic Ocean. The combination of these factors explains why we have some of the highest precipitation in the world.

The rock types in this area consist of sedimentary deposits and volcanic rocks. Most of the hills surrounding this city are pyroclastic cones which are rapidly undergoing deep weathering. The sedimentary rocks along the coastal lowland consist of sands and gravel with mud beds and pyroclastic materials. The surface area is covered with red or reddish brown soils. The soils are either Andosols on sloping ground derived from basaltic lavas and associated igneous rocks or various sub-divisions of fluvisols on rivers, estuarine and marine alluvium (Lambi et al., 1991).Young volcanic soils formed from volcanic ash, cinders, weathered basalts from lava flows or loose pyroclastic material are well developed here and constitute most of the volcanic cones that surround Limbe (Lambi et al., 2002).

The city has attracted people from the Cameroonian hinterlands in search of better economic opportunities principally because of its position as the seat of the country's lone refinery and a commercial centre. The consequence was an unusual influx of people into the city which neither has an adequate scheme and suitable land for settlement. The rapid growth implied that there was maximum encroachment onto marginal lands such as marshes and steep slopes. The population increased rapidly from 51,000 inhabitants in 1976 to over 80,700 inhabitants in 2000 (Cameroon Statistical Year Book, 2000) giving a very high population density of inhabitants per $\mathrm{km}^{2}$. This low-lying coastal plain does not only carry the congested built up area but also part of the Cameroon Development Corporation's oil palm plantations. From the land use map of this area, it is evident that the plantations occupy most of the favourable foot slope areas leaving the population with limited space for settlement. They are therefore forced to encroach into marginal areas with all their risks. The result has been the growth of slums on these marginal and high-energy areas.

\section{Results}

Limbe is plagued by a number of geomorphic and geologic phenomena - floods, landslides, coastal erosion, earthquakes and volcanic eruptions. These are normal earth processes that have made our earth what it is today 
(Cunninghan et al., 1997). Landslides or slope failures which bring disasters here are rapid and complex phenomena as they have their origin from a number of factors. The trigger mechanism for the catastrophic mass movements could be earthquakes, man's activities, unfavourable geologic structure and heavy precipitation. The natural processes by themselves can generate landslides irrespective of human activities. However, experience from Cameroon and other parts of the world points to the fact that man's activities such as real estate construction and overgrazing on steep slopes are some common human factors which sometimes combine with the underlying geological structure to bring about massive slope failure.

While physical factors have had their role to play, it is obvious that town planning lapses in Limbe and human interference on weathered fragile hill slopes have accelerated the frequency of landslides in Limbe. Although the torrential rainfall primarily triggers the landslides in Limbe, there is no doubt that anthropic activities have increased their prevalence and intensified their magnitude. By way of contrast, the Moliwe - Bonadikombo Livanda II hills toward the east which have a high degree of freedom have no landslides or other forms of slope failure. Rainfall acts as a trigger element of landslides especially during peak months of rains Ngakfumbe, 1989 (). Data collected from the field reveal that most of the landslides in this area occur during peak months of the rains (June, July \& August) when the soils are already saturated. It was observed that 35 of the landslides recorded in the area in course of this research did occur within this period. This therefore goes to confirm the fact that rainfall is one of the major factors responsible for the landslides here. Since the region is made up of weathered volcanic soils, they are easily saturated. These soils are prone to landslides as they contain inter-bedded layers of shales and clay which easily form sliding surfaces especially if the slopes angles are high. Scars left by the Mabeta landslides in Limbe had a height of over $20 \mathrm{~m}$ at the widest point; the width ranch from $30 \mathrm{~m}$ to $40 \mathrm{~m}$ with slope angle between $40^{\circ}$ to $60^{\circ}$. Other landslides occurred on slopes between $30^{\circ}$ to $45^{\circ}$ (Table 1). In such a saturated state, the weathered rocks readily produce a spontaneous slope failure if triggered by a minor earthquake. With the frequency of earthquakes in this region and especially, the series of earthquakes that hit this region prior to the 1999 and 2000 Mount Cameroon eruption, such slides were evident after the continuous and heavy rains that were recorded in June of 2001 for example, especially as cracks (geologic weaknesses) would have been created in this area after these seismic activities (Ayonghe et al., 2002).

Table 1. Estimated slope angles and nature of man's activity on some sites in Limbe

\begin{tabular}{|c|c|c|c|c|}
\hline Sites & $\begin{array}{c}\text { Estimated } \\
\text { slope angles }\end{array}$ & $\begin{array}{l}\text { Nature of weathered } \\
\text { scoriaceous material }\end{array}$ & Man's Activity & Geomorphic processes \\
\hline $\begin{array}{l}\text { Mabeta - } \\
\text { Towe } \\
\text { Hills }\end{array}$ & $40^{\circ}-60^{\circ}$ & $\begin{array}{l}\text { Weathered red-brown } \\
\text { scoriaceous materials }\end{array}$ & $\begin{array}{l}\text { Building and farming } \\
\text { of food crops }\end{array}$ & Landslides, Mudflows \\
\hline $\begin{array}{l}\text { Mbende } \\
\text { Hills }\end{array}$ & $30^{\circ}-45^{\circ}$ & $\begin{array}{c}\text { Dark brown to red earth; } \\
\text { slippery when saturated with } \\
\text { moisture }\end{array}$ & $\begin{array}{c}\text { Dense human } \\
\text { settlement, small } \\
\text { scale farming around } \\
\text { houses }\end{array}$ & $\begin{array}{l}\text { Observed creep and } \\
\text { gullying }\end{array}$ \\
\hline $\begin{array}{l}\text { Coconut } \\
\text { Island }\end{array}$ & $45^{\circ}-55^{\circ}$ & $\begin{array}{l}\text { Dark brown to red earth; } \\
\text { slippery in the rainy season or } \\
\text { when saturated with moisture }\end{array}$ & $\begin{array}{c}\text { Dense human } \\
\text { settlement, small } \\
\text { scale farming around } \\
\text { homes }\end{array}$ & $\begin{array}{l}\text { Creep reflected in the } \\
\text { sinking and tilting of } \\
\text { houses }\end{array}$ \\
\hline $\begin{array}{l}\text { Mile } 2 \\
\text { Hills }\end{array}$ & $24^{\circ}-40^{\circ}$ & $\begin{array}{l}\text { Red brown scoria; slippery in } \\
\text { wet conditions; chalky or } \\
\text { whitish in dry season; thus } \\
\text { high clay content }\end{array}$ & $\begin{array}{l}\text { Human settlement } \\
\text { and subsistence } \\
\text { cultivation }\end{array}$ & Fluvial erosion, gullying \\
\hline $\begin{array}{l}\text { Mbonjo } \\
\text { Quarter }\end{array}$ & $40^{\circ}-60^{\circ}$ & $\begin{array}{l}\text { Weathered brownish scoria } \\
\text { with high clay content }\end{array}$ & $\begin{array}{l}\text { Human settlement, } \\
\text { food crop afrming }\end{array}$ & $\begin{array}{l}\text { Subterranean flow of } \\
\text { water all year round } \\
\text { (springs, sapping and } \\
\text { gullying }\end{array}$ \\
\hline
\end{tabular}

The table shows the average slope angle for the humanized volcanic hills which characterize the major residential areas of the Limbe Municipality. It also indicates the anthropogenic activities and geomorphic processes which characterize the residential areas. Source: Kometa, 2001. 
Urban development on many of these scoriaceous hills (Table 1) tends to show a cruel paradox in spite of the already delicate geological setting of Limbe. Such settlements invite disaster even without the advent of seismic tremors. The foundations of such homes are not suitably designed to withstand failure. At the Mabeta New layout in 2001, two adjacent or twin landslides claimed at least 23 lives. Some of those who died were simply buried in their houses. Other houses at the foot of the Mabeta hills were equally swept away by current of water rushing down slope with all that was inside. The landslide which occurred at Mile 2 resulted in the down slope movement of a huge quantity of regolith mixed with water that completely damaged six houses on its way. Other materials made up of mostly boulders completely blocked the main road making it impossible for the passage of vehicles.

Coastal environments are very sensitive to change and have long been desirable locations for human settlement and development. Since such sensitive and vulnerable areas possess elaborate infrastructure, they are subjected to threats by coastal erosion, flooding and storm disasters. The settled part of Limbe extends to the coast line with pronounced arms of the sea which stretch into land (Figure 1). Moreover, much of the underlying bedrock of Limbe is generally overlain by recent pyroclastic deposits which are extremely susceptible to coastal erosion. The exposure of this coast to prevailing winds and to the open sea, is thus of vital importance. Such exposure means that the coast is open to attack by powerful sea waves.

During heavy rains in June 2001, the level of the sea rose and huge masses of water were forced to crash on the coast. The foundation of the building housing the Red Cross as well as part of the main road linking this area to the rest of the town especially around the BEAC (Bank of Central African Region) junction were eroded (Figure 2). The intensity was so strong that both the building and the road collapsed. The engineering company which constructed the road did not take the local geology into consideration. Since this area is made up of mostly volcanic scoria which is easily weathered, chemical weathering took place and rendered the rocks susceptible to erosion. No supporting embankment existed and those there today only came after the 2001 disaster (Figure 3).

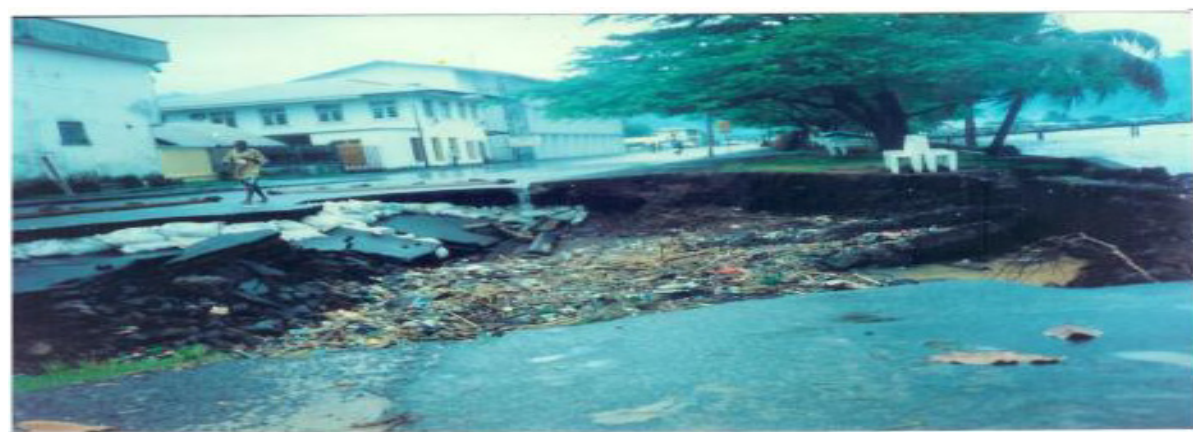

Figure 2. The main road at 'Down Beach' eroded by oceanic waves in June 2001

The figure shows the overwhelming energy of the sea waves given the partial collapse of the road in the area noted.

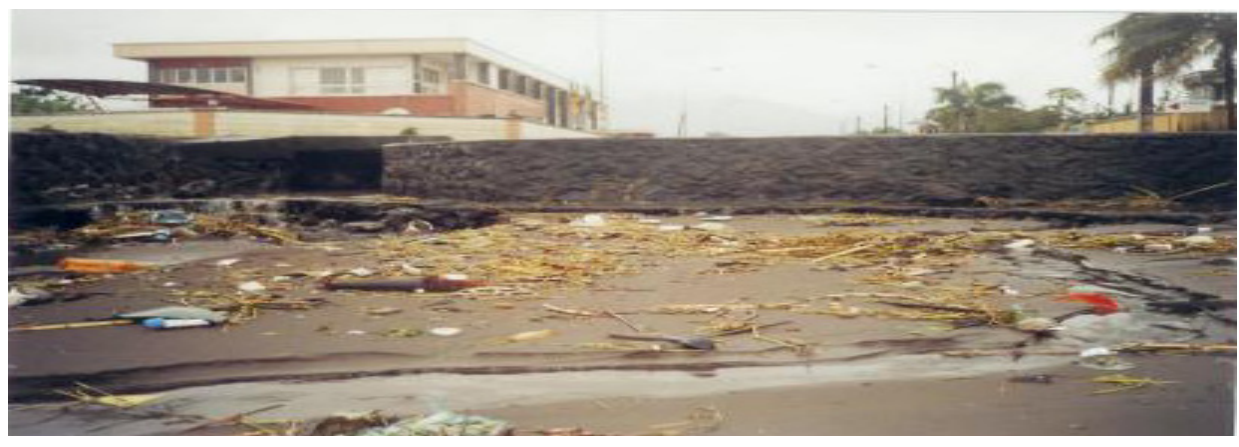

Figure 3. The same road at 'Down Beach' rehabilitated in 2004

The figure shows some rehabilitation effort in progress three years after the collapse portion of the road indicated in Figure 2. 
Throughout history, floods have shaped the landscape, provided habitat for some wildlife and created rich soils. Equally, floods have constituted some of the greatest examples of disaster, disrupting lives and often causing significant economic losses. In the last decades, the consequences of flood events have been devastating for Limbe, especially the poor. These urban poor have fewer resources available and their livelihoods are more vulnerable to the risk associated with flooding and are more susceptible to disruption. Generally, women within this community take much of the responsibility as they do not only deal with the economic devastation but are also left to cope with the social and emotional upheavals that come from dealing with death, disease and food shortage that invariably occur in the aftermath of floods.

The topographic layout of Limbe shows a basin-like structure with a number of topographic elevations (Figure 4). This basin or coastal plain stretches for about 3 to $4 \mathrm{~km}$ from the sea and some of the built-up areas are only slightly above sea level making the soils constantly saturated. This problematic area of Limbe shows a low lying area dotted by a number of scoriaceous cones and this plain is ensconced by hills except in the south eastern portion where it opens into the Atlantic Ocean. Urban flooding in Limbe is therefore not recent but it has been more disastrous in the past decades because of the rapid growth the town has been witnessing. This with the site, relief and geology, the rainfall and drainage characteristic of Limbe make it an environment rife for persistent and disastrous flood hazards (Lambi et al., 2002). Topographically, most of the settled area is only a few meters above sea level which is thus served by rainstorms from the surrounding hills (Figure 5) that channel water in a 'funnel-like manner' into the city. This flooding is therefore made worse by the extremely low relief and the inadequate or poorly maintained drainage systems.

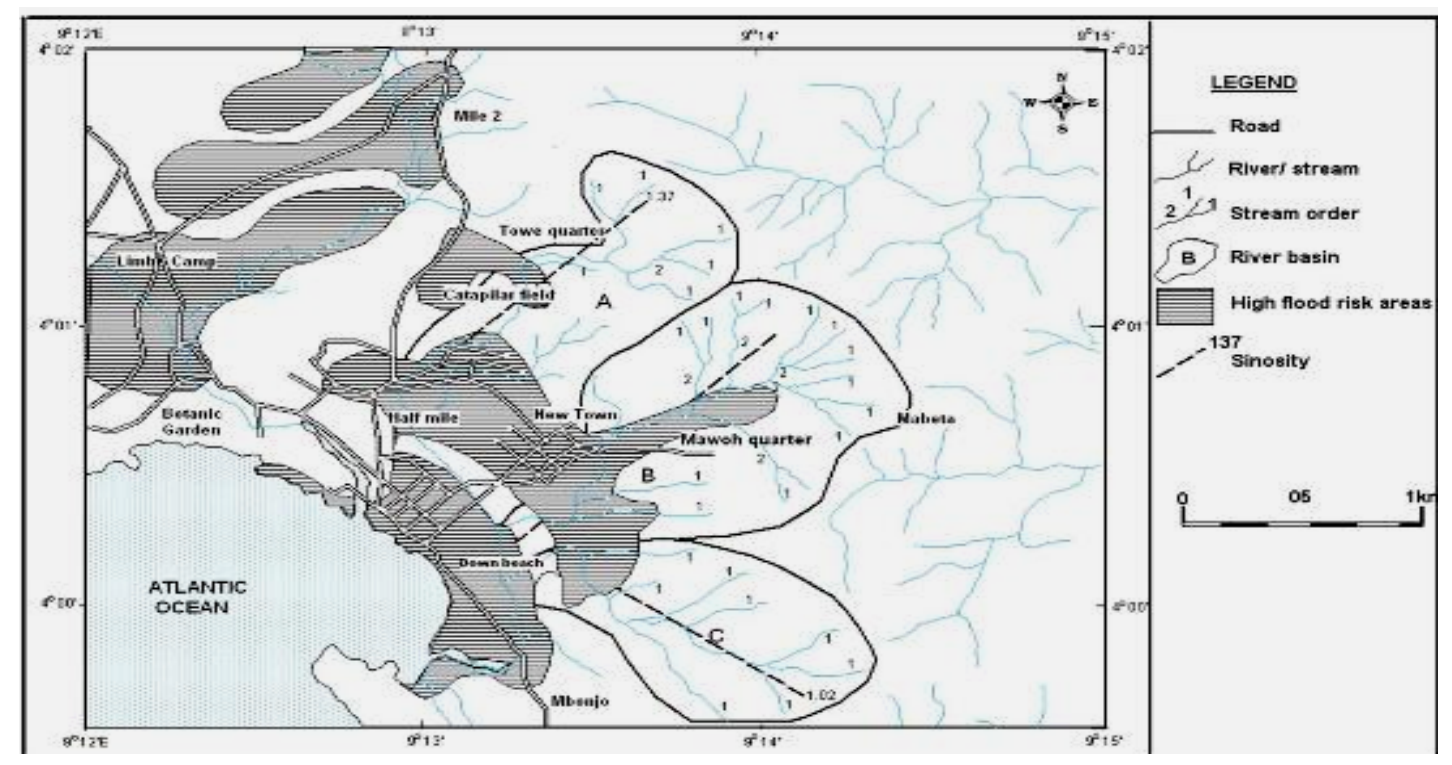

Figure 4. Flood-prone area in and around Limbe

The figure is a presentation of the humanized flood-prone areas in relationto their proximity to the natural drainage channels and the sea. 


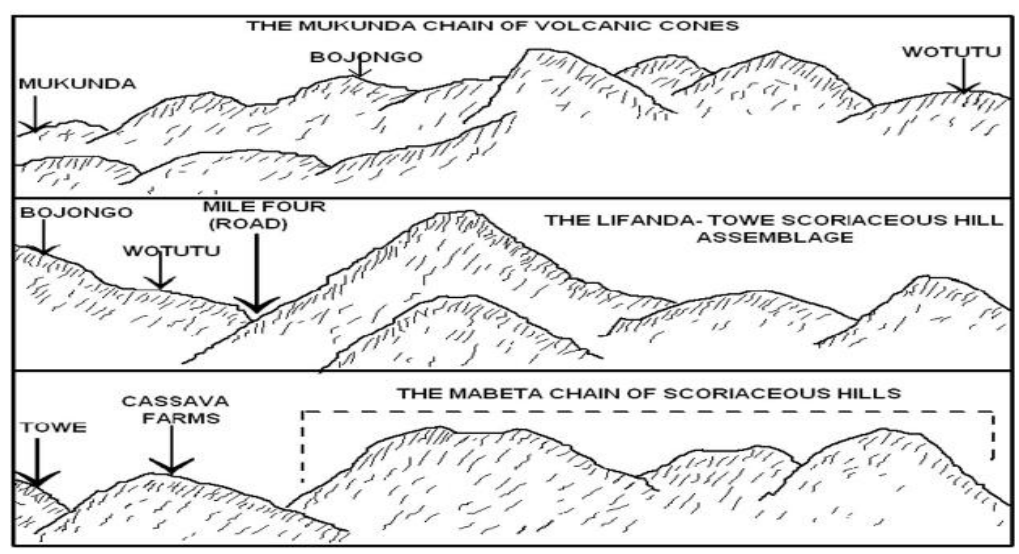

Figure 5. The surrounding scoriaceous chains of volcanic cones which make up funnel shaped topography that ensconces Limbe. Source: Adapted from Figure 1

The figure gives a picture of the topographic nature reflected in the chains of scoriaceous cones which partially surround the fllod-prone lowlands in the study area.

As far back as the 1960s, some of the wetland areas were perceived as unsuitable for human settlement. Prominent among these are the 'Clerks Quarter' and the 'Motowo Quarter' otherwise known as 'Crab Quarter'. These seasonally flooded areas posed no problem to the inhabitants and the municipal authorities of the town then known as Victoria. However, population has grown from 51,600 in the 1970s to over 100,000 in recent years. This population increase came along with an increase in solid waste production some of which is dumped directly into drains which are already too small to carry runoff. The illegal dumping of garbage in the Jengele stream, for example, has turned it into a pseudo-dump site, thus clogging the water passage so that water flows sluggishly and with difficulty into the sea. In this way, flooding here is largely human-induced. The drainage network is poorly conceived while other areas are worse off with a total dearth of these structures. Consequently, whenever there is heavy rainfall, the natural waterways and existing drainage facilities cannot accommodate the volume of surface run-off due to increasing urbanization. Where drains have been provided, they are indeed too small in the first place and totally inadequate to carry the torrential runoff. The average percentage effectiveness of the drains in this area when calculated gave us $56.77 \%$.

In some areas, houses are constructed across waterways and when it rains heavily, these houses block the course of water and the level of flood water that invades these houses is above $1 \mathrm{~m}$ (Table 2). In other areas where reclamation has taken place, there are no retaining embankments. Flooding here has left a lot of people homeless and with contaminated water supplies. From statistics gathered from the field a lot of quarters in this city suffer from flooding. During the 2001 flood disaster, the Atlantic Ocean provided a navigable waterway to New Town, enabling stranded people to be ferried by flying boats to somewhere after the New Town market as the whole of area from the Atlantic Ocean coast to the New Town market was flooded for days. The water a level when there is flooding are usually above $1.5 \mathrm{~m}$. 'Cassava Farm', 'Lumpsum' quarters and Church Street (which is relatively low-lying) were partially submerged and debris brought down from 'Cassava Farm' spread over the entire area providing a thick layer of mud. The areas near the River Limbe are usually submerged as the River overflows its banks.

Table 2. Location, Dimension and Height of Flood peak around some Quarters in Limbe (2001)

\begin{tabular}{lcc}
\hline Area/Location & Dimension at peak Period & Flood peak Height \\
Church Street/Cassava Farm & $80-250 \mathrm{~m}$ & $1.0-1.3 \mathrm{~m}$ \\
Clerks Quarters/Lumpsum & $80-300 \mathrm{~m}$ & $1.0-1.5 \mathrm{~m}$ \\
Motowo/ Jengelle Quarter & Very extensive & $1.5-2.0 \mathrm{~m}$ \\
Mawo Quarter & Very Extensive & $1.5-2.0 \mathrm{~m}$ \\
\hline
\end{tabular}

The table is a presentation of the urban residential topographic lows in relation to the extent of the rise in flood waters during peak rainfall. Source: Lambi et al., 2002. 
Even with improved ability to identify hazardous areas and warn of impending eruptions, increasing numbers of people face certain danger. Scientists have estimated that the population at risk from volcanoes is likely to increase in the next decades (US Department of Interior, 2000). Clearly, scientists face a formidable challenge in providing reliable and timely warning of eruptions to many people whose settlements are close to active volcanoes. Nowhere else in Cameroon has there been the threat of a volcanic eruption than around Mount Cameroon. Mount Cameroon has in recent years attracted much attention because of the 1982, 1999 and 2000 volcanic eruptions and the gas emissions from Lake Monoun and Lake Nyos in 1984 and 1986 respectively, which claimed nearly 2000 lives. This mountain which is $4095 \mathrm{~m}$ high, is situated in the central region of the Cameroon Volcanic Line (CVL) - a 1600km long chain of Tertiary and Recent Volcanoes that stretch from the Atlantic Island of Pagulu to the interior of the African continent. Given present day developments in Limbe, it is obvious that if any future eruptions were to occur close to this city or along the coast with a greater magnitude, it would probably result in a major disaster here. The most catastrophic disaster from volcanic eruption has been the one of March 1999, which ruined the Green Valley oil palm plantation along the West Coast of Limbe.

When we consider that the growing population of Limbe lives in earthquake-prone areas, it becomes necessary for research in the area on earthquake prediction, control and engineering in order to cope with future seismic impact. Though negligible damage to houses and property has usually been the case, the effects of these earthquakes and their suddenness always terrify the local population. With the location of epicenters (Figure 6) close to Limbe and off the coast of Limbe, the population needs to be constantly enlightened on ways of managing the effect of earthquakes and the possible occurrence of tsunamis. Though most earthquakes in this area have often been of low intensity and magnitude, there are possibilities that we might have some in the future with greater intensity and magnitude as this city is located along the Cameroon Volcanic Line (Ateba and Ntepe, 1997). Furthermore, if these epicenters were to fall exactly on the fault lines which exist in this area, the destruction will be greater.

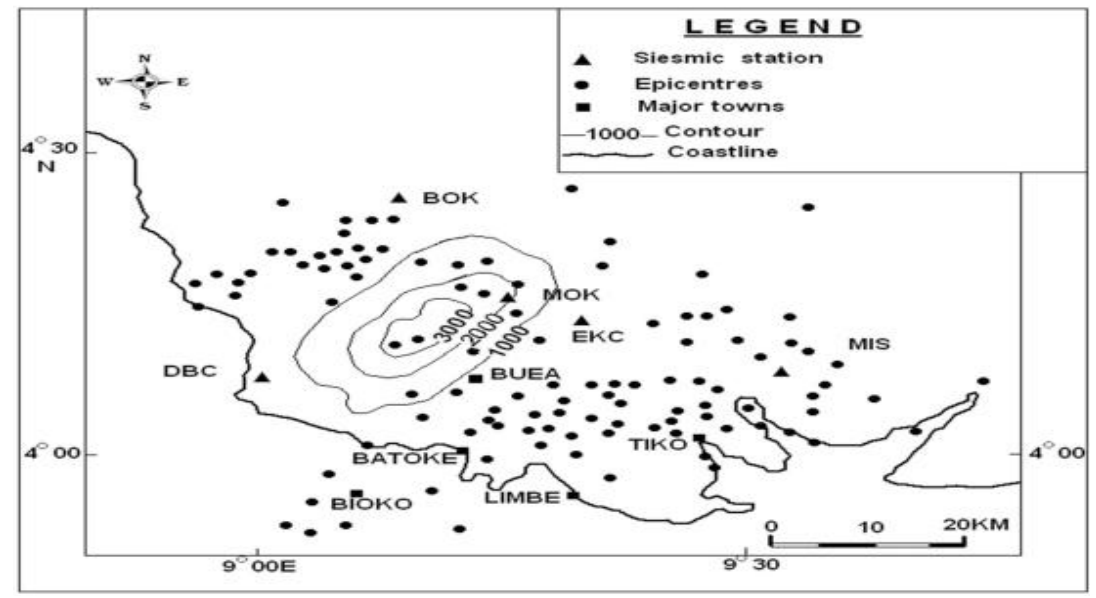

Figure 6. The distribution of earthquake epicenters around the Mount Cameroon Region

The figure shows the distribution of earthquake epicenter in the Mount Cameroon Region. It is important to note the occurrence of major residential centers relative to the earthquake epicenters. Source: Ateba and Ntepe, 1997.

\section{Discussion}

Human settlement on loose, unconsolidated materials, be it volcanic scoria like the case of the Limbe pyroclastic deposits poses enormous ris for mankind. Although scoriaceous cones are known to be stable because they possess a high degree of porosity, human interference makes them potentially dangerous. In Limbe, two basic terrain characteristics enhance instability, namely, the loose nature of the pyroclastic ejecta and the anomalously steep slopes upon which there is need for effective land management. The historical review of landslides in Cameroon shows their concentration along the CVL and most of them occur during the peak of the rainy season when the soils which have been heavily weathered become saturated. This and other factors (human and seismic activity) account for the occurrence of landslides in Limbe. If we look at the epicenters of most of the recorded earthquakes around the Mount Cameroon, a good number of these are located close to Limbe. This falls in line with the orientation of the fault line that runs through this region in the SW-NE direction. 
The seismicity of the Mount Cameroon region is characterized by the occurrence of both single and multiple earthquakes. The occurrence of earthquake swarms in volcanic areas is a fairly common phenomenon. Although all recent eruptions of Mount Cameroon are associated with felt earthquakes, some of these swarms are related to existing faults suggesting that the seismic activity seems to be controlled by the tectonic setting of the volcano. A society therefore that is prepared for an earthquake is more likely to suffer less than one which is totally unprepared.

With most of the suitable areas occupied by the Cameroon Development Cooperation plantations, most migrants who are generally poor are pushed to the hill slopes and wetlands. Limbe, like most towns in Cameroon is poorly planned. With an influx of population from the rural areas into the municipality the migrants cling to these cheap and available marginal lands where there are no strict urban laws prohibiting settlement in these risk areas. It is however, only the urban poor who settle in these areas and that is why when landslides and floods occur, it is only the urban poor who bear the losses. The municipal authorities should prohibit settlement in these areas but when they remain indifferent, squatters settle at the precarious sites. Over the past decade, there has been dredging, widening, straightening and deepening of stream channels to reduce the flood risks When the stream channels are straightened, the water flows freely but when there is a lot of meandering of the river channels, the flood intensity is high, especially when the rains are heavy and prolonged.

Based on the DRI, we concluded that risk in Limbe is not caused by hazardous events per se, but has been intensified through human activities. Consequently, the risks of death, being displaced, or loss of property are only partially dependent on the physical environment. On the other hand, physical exposure is not an indicator of vulnerability, but is a condition sine qua non for disaster to exist. Without people exposed to hazardous events, there is no risk to human life. Greater physical exposure therefore leads to greater loss of life and property. The assessment of vulnerability in the area considered variables that may have increased the severity, frequency, extension and unpredictability of a hazard. For example, deforestation along hill slopes for settlement and agriculture may increase landslides hazard. Thus, those development activities that influence hazards as well as those that influence human risk are considered as vulnerability. Also included are those factors that may decrease vulnerability, such as appropriate development and urban planning and specific actions to mitigate hazard losses. However, in Limbe, those variables that make people vulnerable to volcanic eruptions and earthquake hazards are not necessarily the same as those that make people vulnerable to coastal erosion, landslides and floods. Each corresponds to a particular configuration of development activity. Hazards affect people's lives and livelihood in many ways. Depending on the type of hazards, people may be killed, houses may be damaged or destroyed, crops may be lost and land may be eroded or washed away.

Since hazards tend to have colossal impacts on man, development and the environment, an impact assessment is much welcome as it enables planners to weigh the odds against the benefits of our environmental activities and decisions. This could reduce the casualty level when a hazard occurs. The nature of urban expansion and development should be meticulously articulated to ensure human safety. Proper environmental planning can reduce the effect of hazards. In the planning process, we should not neglect the fact that there is adequate geological and topographic data which can be exploited in order to avoid faulty engineering designs. The landslide risk assessment for example, is supposed to examine the potential for slope failure. Making use of some of these parameters for simple slope analysis and land use types using satellite imagery and aerial photographs will greatly reduce the risk from hazards.Given the damage which eruptions can cause, the prediction of volcanic occurrences is vital in reducing the loss of human lives and property. While it is abundantly clear that it is difficult to control volcanic eruptions, scientists and the government of Cameroon should provide adequate information to those who live close to these active tectonic areas so that damage can be kept to the barest minimum. Also, as landslides are frequent on the steep and deeply weathered scoriaceous hillsides, such slopes should be liberated from all forms of human activity and the council should encourage re-afforestation on these hill slopes.

\section{Conclusion}

Low-lying areas liable to periodic and permanent flooding should be evacuated completely. The return period of catastrophic floods is so short and cannot be easily established because of climatic variation from year to year. An alternative land use proposals should be put in place by the municipal authorities for the flood prone zones. In Limbe, it is a cruel paradox that plantation agriculture has taken some of the best land while the greater population is forced onto risk prone zones. Given the frequency of hazards here, it is important for the government of Cameroon to re-examine the pressing question of human settlement vis-a vis the creation or expansion of agro-industrial plantations. The nature of our urban expansion and development should be meticulously articulated to ensure human safety. This implies careful planning based on geology and hazard 
planning. With good and careful planning, future development schemes should anticipate and put in place strategies to prevent possible human induced hazards. Natural hazards are not always detrimental to humankind. Some may provide a service, such as fertile soil around volcanoes and the renewal of mineral nutrients on a flood plain. For the Limbe municipality, a proper coastal protection and management scheme should be put in place since nothing else has been done after the period of the German colonization of Cameroon when embankments were built. The municipal authorities should consider giving maintennance of drains a priority.

\section{References}

Ateba, B., \& Ntepe, N. (1997). Post-eruptive Seismic Activity of Mount Cameroon, West Africa: A statistical Analysis. Journal of Volcanology and Geothermal Research, 79, 25-45. http://dx.doi.org/10.1016/S0377-0273(97)00022-X

Ayonghe, S. N., Suh, C. E., Ntasin, E. B., Samalang, P., \& Tantong, W. (2002). Hydrological, Seismically and tectonically triggered landslides along the Cameroon Volcanic Line, Cameroon. Africa Geosciences Review, 9(4), 325-335, France.

Blaikie, P. et al. (1996). At Risk: Natural Hazards, People, Vulnerability and Disasters. Routledge.

Cunningham, P., \& Saigo, W. (1997). Environmental Science: A Global Concern (4th ed.). London: Brown Publishers.

De Melo, L. G., Wolle, C. M., Motidome, M. J., \& Altrichter, G. (2003). Major landslides triggered by the December 1999 intense rainstorm in the Serra do Mar Mountain Range, Brazil. Landslide News, 14/15, 48-50, Kyoto, Japan.

Dinar, A., Hassan, R., Mendelsohn, R., Benhin, J., Lambi, C. et al. (2004). Climate Change and Agriculture in Africa. Impact Assessment and Adaptation Strategies. London, UK: Earthscan.

Goudie, A. (1990). The Human Impact on the Environment (3rd ed.). Cambridge: MIT Press.

Kometa, S. S. (2001). Human adaptation in the Tiko Estuarine Environment. In. C. M. Lambi's Environmental Issues: Problems and Prospects, Unique printers Bamenda, pp. 147-157.

Lambi, C. M., Kometa, S. S., \& Fombe, L. F. (2002). Environmental Hazards and Landuse Planning for Sustainable Development: The Limbe Unstable Coastal Region, Cameroon. In: Instability, Planning and Management, Edited by R.G. Mcinnes \& J. Jakeways, Thomas Tefford, pp 151-159.

Lambi, C. M., Kometa, S. S., Fogwe, Z. N., \& Apiapuh, G. E. (2001). The May 2000 Enigmatic Volcanic Eruption of Mount Cameroon: What Lessons? In: Lambi C. M., \& Eze B. E. (2001), Readings in Geography, Unique printers Bamenda. pp 60-68.

Mendes, M. H., \& Costa, F. L. (2001). Volcanic Hazards in the Fogo Island, Cape Verde. Journal of the Geoscience Society of Cameroon, 1(1A), Yaounde

Ngakfumbe, S. N. (1989). Spatio-Temporal Analysis of Rainfall Over Cameroon, PhD Thesis, University of Ibadan, (Unpublished).

Nieuwolt, S. (1978). Tropical Climatology: An Introduction to the Climate of the Low latitudes. New York, USA: John Wiley and sons.

Smith, K. (1996). Environmental Hazards, Assessing Risk and Reducing Disaster. London, New York: Routledge.

Ubangoh, R. U., Ateba, B., Ayonghe, S. N., \& Ekodeck, G. E. (1997). Earthquake Swarms of Mount Cameroon, West Africa. Journal of Africa Earth Sciences, 24(4), 413-424. http://dx.doi.org/10.1016/S0899-5362(97)00072-9

UNDP. (2002). A Climate Risk Management Approach to Disaster Reduction and Adaptation to Climate Change. UNDP Expert Group Meeting, Havana, Cuba, June 19-21

UNISDR (United Nations International Strategy for Disaster Reduction). (2001). Report of Working Group 3 to the ISDR Inter-Agency Task Force for Disaster Reduction, 2001.

United Nations Development Program. (2002). Human Development Report. New York: Oxford University Press.

Winchester, P. (1992). Choice and Vulnersability: A Case Study in Disaster Management in South India. London: James and James Science Publishers. 